\title{
The Empty Field (Puste pole)
}

\author{
Author: Tadeusz Hołuj
}

First Published: 1963

\begin{abstract}
About the Author: Tadeusz Hołuj (1916 in Cracow - 1985 in Cracow) was a poet, prose writer, and playwright. After graduating in Polish philology and law at the Jagiellonian University, he worked as an editor for the magazine Nasz Wyraz, as well as taking part in the September 1939 campaign against Germany. During the German occupation, he joined the resistance group Union of Armed Struggle (Związek Walki Zbrojnej), and was later arrested and imprisoned in Auschwitz and Flossenbürg concentration camps, where he joined the camp resistance movement. After World War II, he was active in the politics of the Polish People's Republic, and a member of both the Communist Party and Parliament.
\end{abstract}

Further Important Publications: Dom pod Oświęcimiem (1948, The House in Oświęcim; drama); Jutrzenka i inne opowiadania (1956, Dawn and other stories; short stories); Koniec naszego świata (1958, The End of Our World; novel).

\section{Content and Interpretation}

Hołuj's novel The Empty Field, alongside Bogdan Wojdowski's short story The Naked Land (Naga ziemia) and The May Beetles (Chrabąszcze) by Marian Pankowski, is one of the few works to question the innocence of the victims of Nazi terror - a Polish national taboo. The story is set in the 1960s at the former site of the Treblinka extermination camp, and involves several former prisoners, including Leon, who now works in the area as a janitor. Because the men know the history of the place and the location of the barracks perfectly, they begin, with the help of local peasants, to search for Jewish gold hidden in block 26 where several transports of Jews were incinerated. The idea that treasure may be buried in the ground beneath the camp comes from Werner, a former commandant of Treblinka (and other sources). It is claimed that Werner himself handed over the treasure during the Munich trial, which took place after the war and was aimed at prosecuting Nazi criminals. The truth of this claim, however, remains uncertain, and many characters in Hołuj's play see it as a legend or rumour. As the work of the diggers proceeds, the plot turns to the figure of the museum director (the Director), who is primarily interested in preparations for the jubilee, and not in the matter of the memorial site or its profanation. We also learn of the private conflicts between the two former prisoners, Adam and Leon, as each one argues for his right to the gold. After the death of Leon, the Director brings in excavators to search the ground - now he too would like to see the gold recovered and deposited in the bank. In the background of these events, a team of filmmakers is creating a documentary on the Holocaust. The actresses taking part in the documentary are forced to act out dras- 
tic scenes in the crematorium - to shave their heads, run naked, etc. - sequences in which Hołuj demonstrates a certain lack of psychological depth. Hołuj's play also seems to lack any kind of metanarrative that would help the audience to distinguish the actors' role-playing from the memories of camp survivors, so that there is no clear delineation between truth and fiction. This is partly deliberate, as the author aims to present us with a confused intermingling of memory and reality, and in this way to explore the virtually schizophrenic reality of Treblinka in the second half of the 20th century. In order to achieve this, he uses a device like the one in Leopold Buczkowski's novel The First Glory, which similarly describes the surroundings of the Bełżec extermination camp in connection with the making of a film on the Holocaust. If the model for this motif is, on the one hand, Shoah by Claude Lanzmann, a documentary nearly ten hours in length, broadcast in Poland for the first time in 1987, it is, on the other, the films reportedly made by an amateur Nazi film crew of Krystian Piwowarski's Women in the Meadow and I, published in his collection $\rightarrow$ More Gas, Comrades! At the centre of The Empty Field we find a plot concerning the dispute over plans to build a memorial on the former site of the extermination camp. Hołuj presents various possible projects to commemorate the site, from anthropocentric to ecological (a proposal to allow the forest to overgrow the former camp). It is the Director who supports the anthropomorphisation of Treblinka, proposing to turn it into a memorial park, erect a monument, fill in the pits, and lay asphalt over the remains, effectively sealing off the underground from any relation with the living. The peasants, however, have landed on an altogether different idea. In need of farmland, they propose turning the site into crops and grassland, without any regard for the human remains that lie beneath them. The project of commemorating the site by paving it over with concrete is criticised by both the gold diggers and the peasants, since it would irreversibly cut off all contact between the living and the land in which the Jews and gold are buried.

\section{Main Topics and Problems}

Hołuj's play engages principally with the discussion on the best way to commemorate the former sites of extermination camps - a discussion that continued with the publication of Jáchym Topol's novel $\rightarrow$ The Devil's Workshop. On the one hand, as written anonymously in The General Weekly, various attempts have been made to demolish and plough these sites. On the other, plans have also been made for commemorating them in a sophisticated manner, drawing on the idiom of modern architecture (as in the proposal for a monument called "The Road", which was submitted for the competition at Auschwitz Birkenau in 1958 by a team of Polish artists led by Oskar N. Hansen). Recent discussions taking the side of non-interference typically argue for leaving trees and other vegetation intact, since removing them would amount to an act of ecocide on the historical site of a genocide. In The Empty Field, the Director is in favour of paving over Treblinka, while peasants would like to plough it. In contrast, the narrative of Leon and Adam presents an image of Treblinka as a kind of El Dorado for gold diggers, reminiscent of attitudes reported by Rachel Auerbach in her 1947 book In the 
Fields of Treblinka. The local population, meanwhile, have been conducting their own excavations for decades, as Irena Grudzińska-Gross and Jan Tomasz Gross write in Golden Harvest (Gross, Grudzińska-Gross, 2012).

Hołuj shows the plunder of Jewish gold and the profanation of mass graves from the perspective of individuals rather than the historical bird's-eye view. As a critique of the myth of the innocence of the Polish Häftling, Hołuj's play does not describe the phenomenon of extermination camp gold diggers in detail (as they are, for example, in Golden Harvest by Jan Tomasz Gross). Conversely, Hołuj breaks new ground by openly portraying the Polish peasants' pragmatic view that the former site of the camps should be given back to farmers and restored to its original purpose as farmland - a subject once considered too controversial for such representations. As one of Hołuj's characters points out in The Empty Field, "people would rather have milk than great mourning” (Hołuj, 1979, p. 147).

\section{Cited Works}

Buryła, S. (2013). Tematy (nie)opisane. Kraków: Universitas. Gross, J. T., GrudzińskaGross, I. (2012). Golden Harvest: Events at the Periphery of the Holocaust. New York: Oxford University Press. Hołuj, T. (1979). Puste pole. In: T. Hołuj, Dom pod Oświęcimiem. Puste pole. Kraków: Wydawnictwo Literackie. Małczyński, J. (2019). The Politics of Nature at the Former Auschwitz-Birkenau Concentration Camp. Journal of Genocide Research, 18.12. Available at: DOI: 10.1080/14623528.2019.1690253. [Accessed: 21.04. 2020].

\section{Further References}

Łysak, T. (2012). Jakiej historii potrzeba? Tematyka obozowa w zapomnianych tekstach Andrzeja Brychta i Tadeusza Hołuja. Kwartalnik filmowy, (77-78), pp. 168-184. Małczyński, J. (2018). Krajobrazy Zagłady. Perspektywa historii środowiskowej. Warszawa: Wydawnictwo IBL PAN. Stępień, M. (1985). Twórczość Tadeusza Hołuja. Warszawa: Wydawnictwa Szkolne i Pedagogiczne. 